Acta vet. scand. $1978,19,535-542$.

From the Department of General Microbiology and Microbial Ecology, Royal Veterinary and Agricultural University, Copenhagen, Denmark.

\title{
THE REDOX POTENTIAL OF GROWING CULTURES OF STREPTOCOCCUS BOVIS ORLA-JENSEN COMPARED WITH OTHER FACULTATIVE ANAEROBES
}

\author{
By \\ J. Wolstrup, S. A. Chaudry* and V. Jensen
}

\begin{abstract}
WOLSTRUP, J., S. A. CHAUDRY and V. JENSEN: The redox potential of growing cultures of Streptococcus bovis Orla-Jensen compared with other facultative anaerobes. Acta vet. scand. 1978, 19, 535542. - The changes of redox potential were measured in growing cultures of three strains of Streptococcus bovis, together with three strains of Staphylococcus aureus and one strain of each of Lactobacillus plantarum, Lactobacillus casei, and Eschericia coli. It was found that both $\mathrm{S}$. aureus and $\mathrm{E}$. coli could reduce the redox potential of the growth medium to very low values (between $-400 \mathrm{mv}$ and $-600 \mathrm{mv})$, whereas the streptococci and lactobacilli were able to cause only slight or insignificant changes of the redox potential. Respirometric measurements confirmed that the capacity of oxygen consumption of $\mathrm{S}$. bovis was very small compared to that of $\mathrm{E}$. coli and $\mathrm{S}$. aureus. On this basis the authors conclude that $\mathrm{S}$. bovis in all probability is unable to contribute significantly to maintenance of the low redox potential of its natural habitat, the rumen. This function must be carried out by other bacteria, such as enterobacteria or staphylococci, which are capable of performing a true, aerobic respiration.
\end{abstract}

redox potential; Streptococcus bovis; ruminants.

Streptococcus bovis was originally isolated from bovine faeces and described by Orla-Jensen (1919). Its normal habitat is considered to be the bovine alimentary tract, and it is a consistent component of the normal rumen microflora. Under normal conditions, however, $\mathrm{S}$. bovis will occur only in comparatively low numbers, one or a few million cells per $\mathrm{ml}$ rumen

- Present address: The Department of Physiology and Pharmacology, University of Agriculture, Faisalabad, Pakistan. 
fluid, thus accounting for less than $1 \%$ of the total bacterial flora (Perry et al. 1955, Hungate 1957, Wolstrup et al. 1974, Hobson 1976).

Streptococcus bovis is amylolytic and pectinolytic and a homofermentative producer of lactic acid. In view of the low number of cells, however, its role in the over-all fermentative activity in the rumen must be negligible, but another function has been ascribed to S. bovis, namely disposal of molecular oxygen introduced into the rumen with feed and water. By this means it is believed to contribute to the maintenance of the low redox potential necessary for normal rumen function, and it has even been included in a defined bacterial flora introduced into gnotobiotic lambs with this special purpose in mind (Lysons \& Alexander 1975, Lysons et al. 1976).

Originally, all lactic acid bacteria were considered to be anaerobes, more or less aerotolerant, but with a strictly fermentative metabolism, devoid of cytochromes and therefore unable to metabolize molecular oxygen. More recent studies have shown that in fact several species of both lactobacilli and streptococci can utilize oxygen and perform oxidative phosphorylations (Whittenbury 1964, Smalley et al. 1968, Mickelson 1969, Gregory $\&$ Fridovich 1974, Yousten et al. 1975). Therefore, these bacteria must be considered facultative anaerobes, but the amounts of oxygen consumed in the respiratory processes of lactic acid bacteria are very small compared to the amounts consumed by normally respiring bacteria.

In view of the small number of cells occurring under normal conditions, it seemed quite improbable to the present authors that $\mathrm{S}$. bovis should be able to play a significant role with regard to oxygen consumption in the rumen. It was decided, therefore, to make a study of the possible effects of $\mathrm{S}$. bovis on the redox potential of its growth environments in comparison to other bacterial species with a more typical respiratory metabolism such as Escherichia coli.

\section{METHODS}

Medium and growth conditions. Bacto-Micro Inoculum Broth $($ Dif $c \circ($ ) was used as growth medium in all experiments. In the first series of experiments the bacteria were grown in test tubes, large enough to allow direct introduction of electrodes (diam. $3 \mathrm{~cm}$ ). Test tubes with $50 \mathrm{ml}$ medium were autoclaved imme- 
diately prior to inoculation resulting in a rather low initial redox potential. In the second series of experiments the bacteria were grown in $250 \mathrm{ml}$ closed fermentor vessels. The medium was autoclaved several days before and transferred to the presterilized fermentor vessel immediately before the start of the experiment, resulting in a growth medium more or less saturated with oxygen. In the first series of experiments the cultures were stirred by shaking at regular intervals, whereas in the second series the cultures were stirred continuously by external circulation through an anaerobic pump. The experimental temperature was $37^{\circ} \mathrm{C}$.

$E_{\text {cal }}$ and $p H$-measurements. Both test tubes and fermentor vessels were equipped with platinum and calomel electrodes for measurements of redox potential, and with a combined electrode for $\mathrm{pH}$ measurements. The platinum electrode was cleaned as prescribed by Jacob (1970).

T a b l e 1. List of bacterial strains used in the experiments.

Streptococcus bovis A

Streptococcus bovis CCM 5614

Streptococcus bovis $\mathbf{1 0 . 2 4 0}$

Lactobacillus plantarum ATCG 8014

Lactobacillus casei

Escherichia coli NCTC 86

Staphylococcus aureus Twort

Staphylococcus aureus 4

Staphylococcus aureus 6
Recently isolated from rumen material Received from Czechoslovak Collection of Microorganisms, Brno

Received from Government Research Institute for the Dairy Industry, Hillerød, Denmark

(Syn. Lactobacillus arabinosus 17-5) Received from American Type Culture Collection

Old laboratory culture of unknown origin

Received from National Collection of Type Cultures, England

Old laboratory culture, originally received from Institut Pasteur, Paris

Received from Institute for Veterinary Microbiology and Hygiene, Royal Veterinary and Agricultural University, Copenhagen

Received from Institute for Veterinary Microbiology and Hygiene, Royal Veterinary and Agricultural University, Copenhagen 
Respirometry. Respirometric measurements were performed using a Gilson differential respirometer. Cells from a 24 hrs. culture were harvested by centrifugation, washed and resuspended in buffer solution $\left(\mathrm{Na}_{2} \mathrm{HPO}_{4} 7 \mathrm{~g}, \mathrm{KH}_{2} \mathrm{PO}_{4} 3 \mathrm{~g}, \mathrm{NaCl} 4 \mathrm{~g}, \mathrm{MgSO}_{4}\right.$. $7 \mathrm{H}_{2} \mathrm{O} 0.2 \mathrm{~g}$ in $1000 \mathrm{ml}$ dest. $\mathrm{H}_{2} \mathrm{O}$ ). Each reaction flask was supplied with $2.5 \mathrm{ml}$ cell suspension and with $0.5 \mathrm{ml} 3 \%$ glucose in the side arm. The experimental temperature was $37^{\circ} \mathrm{C}$.

Bacterial strains and inoculation. The bacterial strains used in the experiments are listed in Table 1. In each experiment test tubes or fermentor vessels were inoculated with $5 \mathrm{ml}$ of a $24 \mathrm{hrs}$. culture grown at $37^{\circ} \mathrm{C}$ in the same medium.

\section{RESULTS AND DISCUSSION}

In the first series of experiments the media were practically devoid of oxygen at the time of inoculation, and the initial redox potential was slightly below zero. Under these circumstances both $\mathrm{E}$. coli and $\mathrm{S}$. aureus proved able to reduce the redox potential to very low values, well below $-600 \mathrm{mv}$. S. bovis strain A caused a slight reduction, whereas L. plantarum was unable to cause any significant change of the redox potential (Table 2).

Table 2. Redox potential $\left(\mathrm{E}_{\mathrm{cal}} \mathrm{pH}\right.$ 7) of bacterial cultures. The bacteria were grown in large test tubes, and measurements were made after $24 \mathrm{hrs}$. at $37^{\circ} \mathrm{C}$. Four independent experiments were made with each strain.

\begin{tabular}{lrrrrr}
\hline & \multicolumn{4}{c}{ Experiment No. } & \\
\cline { 2 - 5 } & 1 & 2 & 3 & 4 & Mean \\
\hline S. bovis A & -156 & -189 & -203 & -192 & -185 \\
L. plantarum ATCC 8014 & -94 & -129 & -71 & -93 & -97 \\
E. coli NCTC 86 & -658 & -629 & -669 & -669 & -656 \\
S. aureus Twort & -492 & -665 & -661 & -632 & -613 \\
Uninoculated & -54 & -67 & -57 & -70 & -62 \\
\hline
\end{tabular}

In the second series the initial redox potential was considerably higher, but the total negativation caused by growth of $\mathrm{E}$. coli and $S$. aureus was of the same order of magnitude, viz. about $500 \mathrm{mv}$, and the effects caused by the two Lactobacillus species were slight and probably insignificant. Of the two strains of S. bovis one (CCM 5614) proved completely unable to affect the 
Table 3. Redox potential ( $\mathrm{E}_{\mathrm{cal}} \mathrm{pH}$ 7) of bacterial cultures. The bacteria were grown in fermentor vessels with continuous circulation of the medium. Redox potentials were either recorded continuously or measured at short intervals during $24 \mathrm{hrs}$. incubation at $37^{\circ} \mathrm{C}$.

Duplicate experiments were made with some of the strains.

\begin{tabular}{|c|c|c|c|}
\hline & \multicolumn{3}{|c|}{ Redox potential ( $\left.\mathrm{E}_{\mathrm{cal}} \mathrm{pH} 7\right)$} \\
\hline & before inoculation & after $5 \mathrm{hrs}$. & after $24 \mathrm{hrs}$. \\
\hline S. bovis CCM 5614 & $\begin{array}{r}173 \\
94\end{array}$ & $\begin{array}{r}137 \\
56\end{array}$ & $\begin{array}{r}111 \\
61\end{array}$ \\
\hline S. bovis 10.240 & $\begin{array}{l}60 \\
79\end{array}$ & $\begin{array}{l}-104 \\
-127\end{array}$ & $\begin{array}{r}-88 \\
-120\end{array}$ \\
\hline L. plantarum ATCC 8014 & 90 & 32 & -20 \\
\hline L. casei & -34 & -53 & -124 \\
\hline E. coli NCTC 86 & $\begin{array}{l}54 \\
20\end{array}$ & $\begin{array}{r}-484 \\
-464\end{array}$ & $\begin{array}{l}-294 \\
-465\end{array}$ \\
\hline S. aureus 4 & 150 & -140 & -403 \\
\hline S. aureus 6 & 79 & -40 & -396 \\
\hline
\end{tabular}

redox potential, while the other (strain 10.240) caused a reduction comparable to that caused by $\mathrm{S}$. bovis strain $\mathrm{A}$ in the first experiments (Table 3 and Fig. 1).

A corresponding difference between these two strains was observed in the respirometric measurements. The oxygen consumption measured for S. bovis CCM 5614 was within the limits of error of the experimental procedure, whereas S. bovis 10.240 showed a significant oxygen consumption, although it was very low compared to the oxygen consumption by $\mathrm{E}$. coli and $\mathrm{S}$. aureus, and it decreased rapidly and ceased completely after a short time (Table 4).

The strong reduction of the redox potential caused by $\mathrm{E}$. coli is in good agreement with previous experience. Growth of this species has even been used as a means of creating a redox potential low enough to allow growth of the most fastidious anaerobes (Smith \& Hungate 1958). The reduction observed in the present experiments also is of the same order of magnitude as that observed by Jacob (1970) in experiments with the closely related Proteus vulgaris. The slower development of the low redox potential in cultures of $\mathbf{S}$. aureus than in cultures of $\mathbf{E}$. coli is also in accordance with the generally recognized lower growth rate of S. aureus compared to E. coli. 

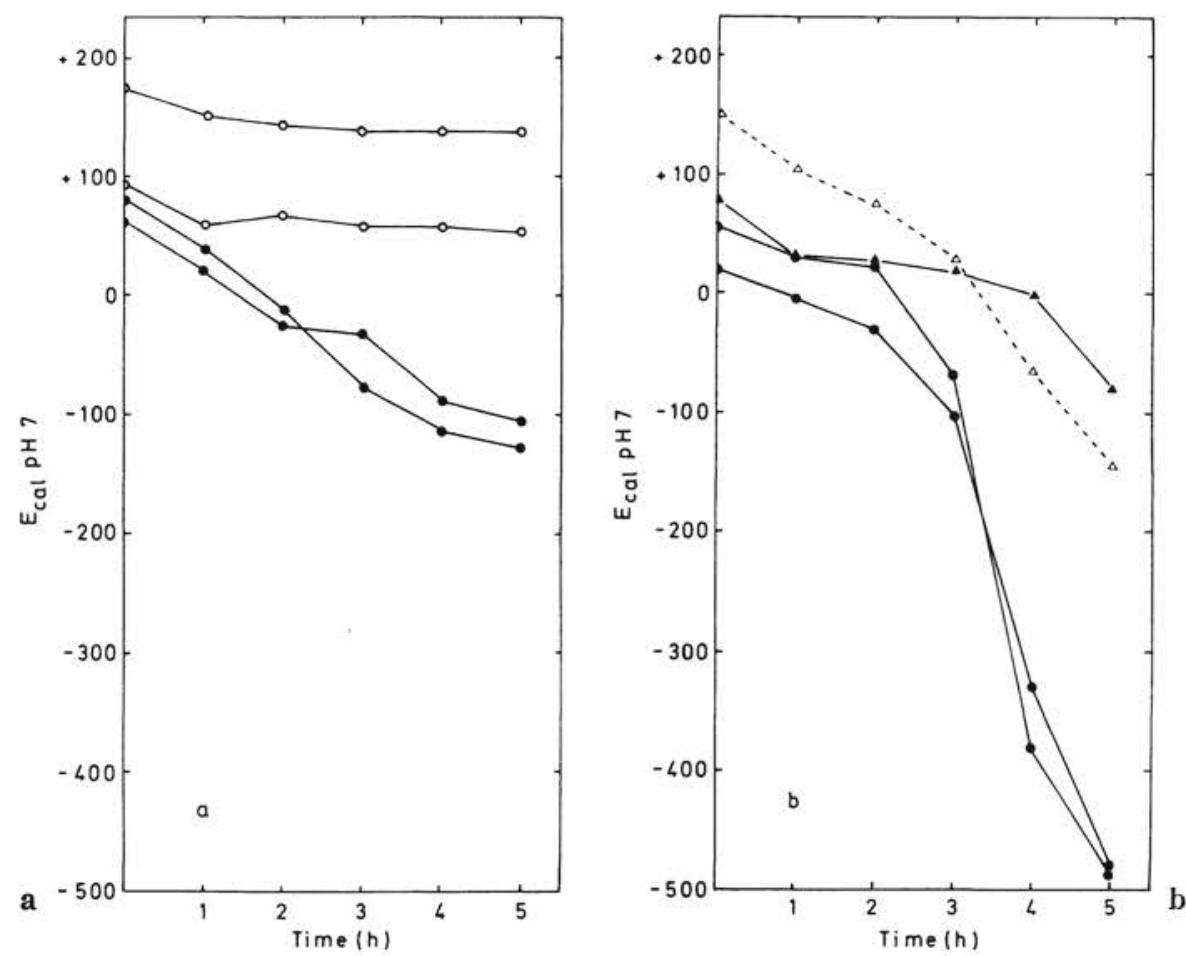

Figure 1. Changes of redox potential ( $\mathrm{E}_{\mathrm{cal}} \mathrm{pH}$ 7) of bacterial cultures during the initial $5 \mathrm{hrs}$. growth in some of the experiments recorded in Table 3 .

(a) Duplicate experiments with S. bovis CCM 5614 (O) and S. bovis 10.240 (ค).

(b) Duplicate experiments with E. coli NCTC 86 (O) and single experiments with $\mathrm{S}$. aureus $4(\triangle)$ and $\mathrm{S}$. aureus $6(\boldsymbol{\Delta})$.

The results obtained with the three strains of $\mathrm{S}$. bovis and the two Lactobacillus species likewise confirm previous findings, namely that some strains of lactic acid bacteria can consume small amounts of oxygen, while others cannot. The effects of these bacteria on the redox potential, however, are always very slight, and it seems highly improbable on this background that they can have any significant influence on the redox potential of the rumen. In the experiments recorded here they were grown in pure culture in rich medium, reaching a final cell density approximating $10^{9}$ per $\mathrm{ml}$ (determined by counting chamber), whereas the density in the rumen normally is about a thousand times lower. 
Table 4. Respirometric measurements. Oxygen consumption by washed cell suspensions was measured by a Gilson differential respirometer during two periods, $0-60$ and $75-135 \mathrm{~min}$. from the start of the experiment.

\begin{tabular}{lcc}
\hline & \multicolumn{1}{c}{$\mu \mathrm{l} \mathrm{O}_{2}$ per mg dry weight per hr. } \\
\cline { 2 - 3 } & $0-60 \mathrm{~min}$. & $75-135 \mathrm{~min}$. \\
\hline S. bovis CCM 5614 & 1.6 & 0 \\
S. bovis 10.240 & 5.3 & 0 \\
E. coli NCTC 86 & 73.1 & 49.0 \\
S. aureus 6 & 104.4 & 95.8 \\
\hline
\end{tabular}

The capability of rumen contents to consume oxygen was proved already by Broberg (1957) to be due to its content of metabolizing microorganisms. However, this capability must involve other species than S. bovis, e.g. enterobacteria, staphylococci, coryneforms and facultatively anaerobic sporeformers. The density of such bacteria in the rumen contents is normally of the same order of magnitude as that of $\mathrm{S}$. bovis, but their capacity of oxygen consumption is many times higher (see Table 4).

\section{REFERENCES}

Broberg, G.: Oxygen's significance for the ruminal flora as illustrated by measuring the redox potential in rumen contents. Nord. Vet.Med. 1957, 9, 57-60.

Gregory, E. M. \& I. Fridovich: Oxygen metabolism in Lactobacillus plantarum. J. Bact. 1974, 117, 166-169.

Hobson, P. N.: The Microflora of the Rumen. Meadowfield Press Ltd., Durham 1976.

Hungate, R. E.: Microorganisms in the rumen of cattle fed a constant ration. Canad. J. Microbiol. 1957, 3, 289-311.

$J a c o b, H$. E.: Redox potential. In Methods in Microbiology 2, 91-123. Ed. by J. R. Norris \& D. W. Ribbons. Acad. Press, London 1970.

Lysons, R. J. \& T. J. L. Alexander: The gnotobiotic ruminant and in vivo studies of defined bacterial populations. In Digestion and Metabolism in the Ruminant. Proc. IV Int. Symp. Ruminant Physiology, p. 180-192. Ed. by $I$. W. McDonald \& A. C. I. Warner. Univ. of New England Publishing Unit, Armidale 1975.

Lysons, R. J., T. J. L. Alexander, P. D. Wellstead, P. N. Hobson, S. O. Mann \& C. S. Stewart: Defined bacterial populations in the rumen of gnotobiotic lambs. J. gen. Microbiol. 1976, 94, 257269. 
Mickelson, M. N.: Phosphorylation and the reduced nicotinamide adenine dinecleotide oxidase reaction in Streptococcus agalactiae. J. Bact. 1969, 100, 895-901.

Orla-Jensen, S.: The Lactic Acid Bacteria. Høst, Copenhagen 1919.

Perry, K. D., M. K. Wilson, L. G. M. Newland \& C. A. E. Briggs: The normal flora of the bovine rumen. III. Quantitative and qualitative studies of rumen streptococci. J. appl. Bact. 1955, 18, 436-442.

Smalley, A. J., P. Jahrling \& P. J. VanDemark: Molar growth yields as evidence for oxidative phosphorylation in Streptococcus faecalis strain $10 \mathrm{Cl}$. J. Bact. 1968, 96, 1595-1600.

Smith, P. H. \& R. E. Hungate: Isolation and characterization of Methanobacterium ruminantium n. sp. J. Bact. 1958, 75, 713-718.

Whittenbury, R.: Hydrogen peroxide formation and catalase activity in the lactic acid bacteria. J. gen. Microbiol. 1964, 35, 13-26.

Wolstrup, J., V. Jensen \& K. Jensen: The microflora and concentrations of volatile fatty acids in the rumen of cattle fed on single component rations. Acta vet. scand. 1974, 15, 244-255.

Yousten, A. A., J. L. Johnson \& M. Salin: Oxygen metabolism of catalase-negative and catalase-positive strains of Lactobacillus plantarum. J. Bact. 1975, 123, 242-247.

\section{SAMMENDRAG}

Redox potentialet $i$ voksende kulturer af Streptococcus bovis OrlaJensen sammenlignet med andre fakultativt anaerobe.

Endringen af redox potentialet under væksten blev målt i kulturer af tre isolater af Streptococcus bovis, tre isolater af Staphylococcus aureus og et isolat af henholdsvis Lactobacillus casei, Lactobacillus plantarum og Escherichia coli. Målingerne viste, at S. aureus og E. coli kunne sænke redox potentialet i vækstmediet til meget lave værdier (mellem $-400 \mathrm{mV}$ og $-600 \mathrm{mV}$ ), medens isolaterne af Streptococcus og Lactobacillus kun reducerede redox potentialet ganske ubetydeligt. Respirometriske målinger bekræftede, at $\mathrm{S}$. bovis kun kunne forbruge ganske lidt ilt sammenlignet med E. coli og S. aureus. Det konkluderes ud fra disse målinger, at $\mathrm{S}$. bovis ikke er i stand til at medvirke væsentligt til opretholdelsen af et lavt redox potentiale i vommen. Denne funktion varetages formentlig af andre bakterier, f. eks. enterobakterier og staphylokokker, som er i stand til at iværksætte en egentlig aerob respiration.

(Received May 8, 1978).

Reprints may be requested from: Jens Wolstrup, the Department of Microbiology and Microbial Ecology, Royal Veterinary and Agricultural University, Rolighedsvej 21, DK-1958 Copenhagen V, Denmark. 